\title{
From confounded to common ground: Misunderstandings between tertiary teachers and students in online discussions
}

\author{
Dianne Forbes \& Dilani P. Gedera \\ The University of Waikato
}

\begin{abstract}
Drawing on findings from two studies, this article focuses on the expectations of students and teachers in higher education, when learning via asynchronous online discussions. In particular, this synthesis highlights a divergence of expectations. The first study investigated how students and teachers experienced asynchronous online discussion within initial teacher education at undergraduate level. The second study examined factors that affect learner engagement within asynchronous online discussions at a postgraduate level. A synthesis of key findings proposes that learning and teaching in higher education can be enhanced by awareness of how participants experience the situation. Common misunderstandings between students and teachers in online classes revolve around presence, formative/summative dimensions, language, and literature. Highlighting misunderstandings enables possibilities for negotiation, change, and improvement. While discussing the common ground for negotiation, this article suggests pedagogical strategies for effective communication and enhancement of online learning in higher education.
\end{abstract}

\section{A tale of two studies}

This article draws on findings from two studies completed in a single higher education institution, focusing on student and teacher expectations in online classes. In each case, the online classes were tertiary level Moodle courses for degree credit that enabled university students to study flexibly and from a distance instead of attending on-campus classes. Each study focused on student experience, alongside the perspectives of teachers and underpinned by the idea that learning and teaching can be enhanced by an awareness of how participants experience the situation. In the context of our studies, a teacher is a lecturer, tutor, or other academic staff member. We have used the term teacher to privilege the teaching role. It is the situation as it is perceived, that is central to the quality of teaching and learning, and this puts participants' experiences at the centre of efforts to enhance pedagogy and deep learning (Brookfield \& Preskill, 2005; Loughran, 2006).

Forbes' (2013) study explored how students and teachers experience asynchronous online discussion within initial teacher education at the undergraduate level. Gedera's (2015) study examined factors that affect learner engagement within asynchronous online discussions in the form of misunderstandings, miscommunication, confusions, and frustrations in two contexts within the same university, at the postgraduate level. A synthesis of these two studies enables original insight into areas of misunderstanding between teachers and students in online discussions.

In her study, Forbes (2013) turned to phenomenography (Marton \& Booth, 1997) to frame the conceptualisation and analysis of participant perspectives by qualitatively describing different ways that students and teachers experience, perceive, and approach online discussions. Forbes (2013) explored student and teacher perspectives of asynchronous online discussions via focus groups with teachers and an online focus group with students as a precursor to individual semi-structured interviews with participants in two core classes. As a further phase, two teachers and seven students were interviewed at strategic points in relation to active online discussions in the curriculum areas of mathematics and literacy education. Teachers and students were asked to explain their thinking at the start of discussion, mid-way through, and at the end of discussion. Analysis of the perspectives of students alongside those of their teachers showed the ways in which the participants viewed discussion quite differently from each other.

In exploring contradictions that affect learner engagement in asynchronous online discussions in two fully online courses, Gedera's study (2015) involved a case study approach with nine students and four teachers. Data were generated using semi-structured interviews, an online questionnaire, online activity observation, and document analysis. Students and teachers were interviewed at the beginning and at the end of the semester. In the interviews, students and teachers were asked to comment on the online discussions they were engaged in. In Gedera's (2015) work, Engstrom's (1987) activity theory was used to help identify 
contradictions within asynchronous online discussions in the form of misunderstandings, miscommunication, confusions, and frustrations. These contradictions included issues related to course materials, grading, communication, and opinions related to teacher's presence.

\section{Are students and teachers on the same page?}

As students and teachers work together online, there are benefits for learning, as well as challenges to surmount, particularly in relation to communicating clear expectations of one another in online discussions. Specific benefits include cost effectiveness, improved access, flexibility, and opportunities for personalised and collaborative learning (Garrison, 2011; Zhang \& Nunamaker, 2003). On the other hand, threats to learning can be due to transactional distance or a lack of relational connection, leading to disengagement and low retention rates (Gedera, Williams \& Wright, 2015). Reduced social cues in virtual environments create challenges for communication. The literature suggests that there are times when students and teachers misunderstand each other's stance and form a false impression of the other's intent and viewpoint (Forbes, 2013; Gedera, 2015). Fundamentally, misunderstanding occurs due to differences in the perceptions of participants in the learning environment. This article draws together a range of perceptions to ascertain key points of disagreement, leading to suggestions for arriving at common understandings.

Participant perspectives are important because different people experience online learning in quite distinct ways. For this reason, Marton and Booth (1997) advocated "learning through the eyes of the learner" ( $p$. 14), a sentiment later re-emphasised by Loughran (1999), Laurillard (2002), and Brookfield and Preskill (2005). While attentive to student perspectives, Salmon (2011) has consistently asserted the need to look "through the eyes of online teachers" (Salmon, 2011, p. 3). A more complete picture is gained by seeking to understand perspectives of both students and teachers, and by examining areas of divergence and disagreement, where participants see things very differently from each other.

Misunderstanding arises because there is a divide between what teachers intend and what students experience. For example, Goodyear (2002) has made the distinction between tasks and activities, where tasks are what the teacher prescribes, and activities are what students actually do. Similarly, Loughran (2006) and Beetham (2007) have recognised that students often hold contrary views about the very intent of the activities in the first place and make sense of the tasks in terms of their own goals and perspectives. It is more difficult to pinpoint what the expectations of each party actually are, how these impact upon student learning, and what the solutions to misunderstandings might look like in practice (Ebrahimi, Faghih, \& Marandi, 2016).

In relation to students' expectations, Visser (2007) has asserted "the need for instructors to know what the learners expect from their online instruction" (p. 106). Visser related expectations to students' needs and wants, stopping short of arguing that teachers must strive to satisfy these while asserting the value of becoming attuned to students' needs for academic and affective support, in order to "bring these expectations to the forefront and build on them" (p. 120). That the support expected by learners may be an area of contention has also been suggested by Sims and Bovard (2007), who have reported:

[A] conflict within online environments, where the expectations of the online learner for regular and frequent support are not necessarily aligned with those of the teachers, who often emphasize self-directed learning and student collaboration in order to support the development of an online community. (p. 163)

This potential divide between teachers' intentions and students' experiences, and between teachers' and students' expectations of learning and support, highlights misunderstandings between university teachers and students in online classes.

There is a great deal of support for students' participatory voice on democratic, ethical, pedagogical, and pragmatic grounds (Bender, 2003; Brookfield \& Preskill, 2005; Sharpe, Beetham, \& de Freitas, 2010; Weimer, 2002). Crucially however, a participatory voice does not mean that students dictate the agenda. Teachers and students have joint responsibility for successful learning. Sharing the perspectives of students and teachers serves to bring these into the open to enable productive negotiation. 
Surfacing misunderstanding determines that space of difference, or how teachers and students may be talking past each other. Where expectations are unclear, the space between participants is arguably akin to a void, a mere distance or divide, characterised by persistent misunderstanding. However, where the expectations are disclosed, negotiated, and shared, the space might be converted to a zone (for proximal development, Vygotsky [1978]): a pedagogical space, promoting growth in understanding and common ground (Ellsworth, 1997). In order to work toward common ground between participants in online classes, this paper discusses the question: What are some common misunderstandings between teachers and students working online in higher education?

\section{Revisiting our data}

Realising areas of synergy between our distinct studies, we re-examined our data to extract and compare findings related to misunderstanding between students and teachers in different cohorts and at different levels of (undergraduate/post-graduate) study in higher education. In doing so, we shared data and areas of convergence and divergence in the emergent themes and patterns, via iterative analysis. We shared data from each study in turn, in order to determine common themes and patterns, as well as areas where the findings differed. Combing through the data several times enabled us to develop a stronger sense of salient points of agreement.

Student participants in study 1 were second year undergraduates in an initial teacher education program (a Bachelor of Teaching degree), with a significant online component. A range of experienced teachers contributed to the study, with both teachers and students engaging in focus groups and a series of semistructured interviews, generating data about experiences and perspectives of asynchronous online discussion in particular. Study 2 involved two case studies with data from semi-structured interviews, a questionnaire, along with observations and document analysis. In both studies, classes employed Moodle as the learning management system. In neither case was the researcher the teacher. Each study met the institutional requirements for ethical research, following the usual protocols for informed consent, right of withdrawal, and confidentiality of participants.

\section{Findings}

Synthesising key findings from the two studies, it is apparent that common misunderstandings between higher education students and teachers in online classes coalesced around four areas:

1. presence and participation: standing back versus standing by,

2. formative/summative dimensions,

3. language, and

4. literature.

Each of these areas of contention will be discussed in turn.

\section{Presence and participation: Standing back versus standing by}

The students in both studies expressed a clear preference that teachers take part in online discussions. They specifically characterised this as presence. For example, in Forbes' (2013) online focus group, Nina (student) explained: "we like our teachers to have a presence online," and reiterated in her individual interview that "it's like you're actually in a classroom with them." The notion of teachers being present in online discussion, actively monitoring and contributing to class on a regular basis, was mentioned by all of the students in study 1 . For Nina, being present meant being around at key points in online discussion: "at least at the start, somewhere in the middle like we have to be and somewhere at the end just to wrap up." For other students, presence meant standing by for back up, with a contribution every 2 to 3 days, or at least twice a week. The students emphasised that they did not expect teachers to post every day, but that they expected teachers to be on stand-by.

In study 2, the students emphasised the need to know the teacher is standing by. As Hannah explained: "you feel the presence. Your teacher is there, you feel like you know that." This begs the question of how students know the teacher is standing by. 
Even when employing tactical wait-time, some teachers signalled presence within discussion. Students reported that a teacher entered discussion to let students know she was reading, but waiting for others to post:

She'll say something like "this discussion's going really well but I can see there's more people to come so I'll give you another day and I'll come in and post again tomorrow", so you know that she's there and you know that she's reading it. (Jacqui, study 1)

This strategy satisfied the students' need to know that teachers were reading/monitoring discussion and standing by. In contrast, students in both studies asserted that they felt disadvantaged by absentee teachers, and claimed they were more active in classes where the teacher was present. When teachers did not interact in discussion, the students said their own engagement with discussion and with the class community was minimal. Students argued that expectations were unclear when the teacher was habitually absent, even when the students said they understood the importance of independent exploration of the topic. A majority of students across the two studies were not convinced of the legitimacy of teachers taking a hands-off approach, or standing back from discussion.

Unaware of student expectations, the teachers described one of their roles as standing back from discussion. Teachers in study 2 preferred to oversee rather than actively participate in students' discussions, while teachers in study 1 said they were careful to avoid dominating discussion, instead aiming to stand back to allow space for students to think and converse:

If you're too dominant and become too much the expert and the person with all the content knowledge that can just dry up the conversation like that. I've been in a situation working with someone who just came in straight away with all the knowledge and all the information. And that just, the students didn't feel safe enough to come in with their viewpoints because it had all been sort of said. (Ji, teacher, study 1)

Some teachers said they aimed to scaffold student contributions more intensively at the beginning of a course, backing off a little, and encouraging student independence, collaboration, and leadership as the semester progressed. Teachers in Gedera's (2015) study believed that their participation in the discussion forum could disrupt the students' discussion by interrupting the flow of conversation or dissuading students from freely expressing opinions.

The teachers explained that they valued discussions where students took the initiative and maintained the momentum. However, the teachers monitored discussion to judge whether and when to intervene, suggesting they were standing by. They noted this was a key skill that required experience to perfect. There is a subtle tension between standing back and standing by. Students across the two studies tended to perceive a lack of overt teaching presence as absence and neglect, and preferred teachers to signal they were standing by. For the teachers' part, standing back was sometimes a deliberate strategy designed to enable students to take the lead in class.

\section{Formative/summative dimensions}

Students expected to receive feedback online within discussion as an inherent part of the activity. In terms of more formal assessment, some classes summatively assessed online discussions while others did not. In our studies, criteria for assessing discussion varied between classes within the same programme. A common expectation was for contributors to make links to each other and weave together theory/reading and practice/experience. Students and teachers were divided about the assessment weightings for discussions, with some wanting discussions to count for more to reflect the time spent contributing. Others explained that they felt a greater sense of freedom to use discussion for learning when they did not have to adhere to summative criteria.

The teachers referred to monitoring discussions for formative purposes because participating with students in discussions identified those who were struggling. The teachers noted that they could then follow up to address misconceptions or to extend ideas within discussions, or via private communication. In relation to summative assessment, teachers in study 1 commented that they found assessing online discussion to be challenging and reported difficulties with establishing assessment criteria, weighting, objectivity, and 
manageability. Teachers said it was extremely challenging to formulate useful and timely feedback for large numbers of students, with any level of individualisation. Overall, teachers were divided on the value of assessing discussion. Some provided a summative weighting for discussion to motivate students, highlighting a perception among some teachers that if discussion were not assessed, then students would not take part. Other teachers reacted against the notion that students participated purely for marks, or that they should be rewarded for meeting this basic expectation. Several teachers felt that discussions functioned as tutorials, supportive of and preparatory for other assignments. In some cases, discussions did not carry summative weightings, but were deemed both a compulsory requirement and a commitment to the community of learners.

In summary, the students and teachers reported some confusion about the balance between learning through discussion and the use of discussion as a summative assessment task. Some students prioritised learning and testing of ideas, while other students regarded discussion as an assessment task and sought to allocate their time in accordance with the summative weighting. While teachers highlighted the formative potential of discussion, some considered it necessary to summatively assess discussion to motivate and reward students for the time and effort involved in contributing. Other teachers and some students reiterated the notion of online discussion as a tutorial and argued that participation should be directed toward preparation for other assigned tasks, along with wider learning.

\section{Language}

A further student expectation relates to the style of language used online. It helps to write as they would talk, they said. Students felt that online communication was better when people wrote sincerely rather than wallowing in academic jargon. Students in study 1 preferred what they called free-flowing language in online discussion, and described this as similar to everyday language as opposed to academic speak. They emphasised clarity and appreciated peers in discussion who could simplify and explain academic concepts.

Teachers emphasised clarity in online discussion, and described their own struggles with crafting discussion entries to avoid misunderstandings. The teachers found online discussion useful for introducing students to specialist terminology in their field, enabling them to use the terminology in context while carefully explaining and clarifying meaning. As Elizabeth explained: "You can greatly influence students by your actual language so I use a lot of academic terms but I explain them" (teacher, study 1).

Students in study 2 were frustrated when they had to follow too many rules when contributing to the forum discussions. For example, the students had to adhere to the word limit, APA referencing style, academic language, and so on. This appeared to frustrate students because they focused on following the rules rather than getting their message across:

I think there should be fewer restrictions like APA referencing is not a must, language is not a must. Because we are thinking of the content rather than how we are putting it into our own words especially for non-native speakers it's very difficult. I think even the native speakers find it difficult to organise their thoughts (Hannah, student, study 2)

\section{Literature}

Closely related to the language of the online class, the students in study 1 expressed particular expectations regarding how literature was used by peers in online discussion. At times, they perceived an absence of critical thinking or consideration of the place of their posting in the flow of discussion:

I see a lot of quoting, retelling, and reproducing rather than critical thinking in discussions, but I feel this is more because the onus on those particular discussions is on showing that literature has been read rather than making real connections to it through group discussion. (Don, student, study 1)

The students characterised this practice as false, irritating, and confusing. The pointlessness of direct quotations from readings was emphasised by one student who remarked that: 
If everyone's just in there quoting the readings ... I'm not learning anything because I've already done the readings. I'm just reading them all again ... I mean, what is so interesting about going into a discussion and re-reading readings? (Dana, student, study 1 )

Many students were critical of the need to explicitly reference readings and considered this made discussion stilted and contrary to the free-flowing discussion they preferred. Students suggested that teachers encouraged this by continually emphasising the need to read, but this was considered by students to be detrimental to discussion:

AOD [asynchronous online discussion] is quite often not authentic. No-one goes around quoting references all the time in their conversations. Authentic to me ... means hearing your voice come through, more than the readings. Instead of pages of copy and paste verbatim. However, I think teachers reinforce this, because they always stress the importance of readings (Sarah, student, study 1 )

The students recognised that overuse of direct quotations in discussion may be a smokescreen to mask a lack of true understanding. Many students admitted to skim-reading, brushing over or completely ignoring postings based primarily on direct quotes from literature:

Scrolling through all these discussion posts that are all direct quotes I don't read them I just skim through them until I get to really specific good points that you can follow on from (Don, student, study 1)

When students posted contributions that were largely comprised of a string of two or three quotations, this was regarded by fellow students as confusing and of little value for learning. The students did not question the value of reading academic literature and regarded it as fundamental to their learning. They appreciated that readings could help them understand what they may not be seeing in schools, represent expert opinion, and enlarge their experiences vicariously. The teachers said that they expected students to link to literature within online discussions, and used readings as a stimulus for online discussion. Teachers deemed readings to be important as they exposed students to perspectives that may differ from their own experiences and served to challenge students' thinking.

In summary, students recognised the need to refer to literature pertaining to their field of study, within online discussion. According to the students, teachers expected particular readings to be completed, and used discussion as a means to check that students were indeed reading the set literature. The key area of misunderstanding related to students who overused verbatim quotes. Reproduction of literature is not what the teachers had in mind with respect to effective use in literature, as the teachers emphasised the integration of the students' own thinking, to subject the readings to critical scrutiny.

\section{Discussion}

This section discusses four key findings arising from synthesising our two studies, in comparison with wider literature. The four key areas relate to teacher presence, assessment, language and literature, each of which is discussed in turn.

\section{Being there: Teacher presence}

While the students in our studies preferred teachers to signal presence, in the wider literature not all published studies are supportive of teacher presence (Ebrahimi et al., 2016). On one hand, high teacher participation in asynchronous online discussion is advocated by numerous researchers (e.g., Blignaut \& Trollip, 2003; Brookfield \& Preskill, 2005; Garrison \& Anderson, 2003; Palloff \& Pratt, 2005), and the importance of teacher presence has been supported by multiple studies in the review of literature carried out by Tallent-Runnels et al. (2006). In short, these studies indicate that students are more active when teachers reciprocate (Dennen, 2005); and the ongoing visibility of the teacher in an online class is associated positively with student satisfaction (Akyol \& Garrison, 2008; Bischoff, 2000; Kehrwald, 2008; Ko \& Rossen, 2004; Lynch, 2004; Visser, 2007). This corresponds closely to the comments from students in our studies, as they wondered where the teacher was, doubted the teacher's commitment to the class and their 
work, longed for feedback and reassurance, struggled to see the point of discussion, and resented any perceived lack of reciprocity.

In pedagogical terms, without scaffolding provided by "active teaching presence," there is a concern that students may remain in "continuous exploration mode" without progressing to more advanced stages of critical thinking and cognitive development (Garrison, Anderson, \& Archer, 2001, p. 10). A similar point was made by Ferdig and Roehler (2003) who emphasised the need for students to be extended to the upper end of their zones of proximal development. In most cases, a teacher's input is needed to extend depth and higher order learning (Bates, 2005; Garrison \& Anderson, 2003; Jacques \& Salmon, 2007).

A contrary viewpoint is the school of thought advocating a hands-off approach from teachers in favour of student-led discussion, where students can exercise more freedom, away from teacher surveillance (e.g., Ben-Peretz \& Kupferberg, 2007; Hew, Cheung, \& Ng, 2010). Durrington and Chien (2004) found that students participated more when peers moderated discussion, rather than when teachers did so. Some students experience teacher presence as oppressive (Fauske \& Wade, 2003). This begs the question of whether the style of teacher intervention in the forum is problematic (e.g., perhaps authoritarian and dominant, as in the case described by Jetton [2003]), and how teachers might model effective rather than oppressive pedagogy, while leaving room for peer moderation.

In order to make space for students to contribute their viewpoints, it is necessary for teachers to periodically stand back or to exercise wait-time in discussion, to allow students time to think (Rowe, 1986). It is significant that this tactic was mentioned more by teachers than students, as the students tended to interpret lack of teacher contribution as absence rather than as strategic. A bridge between standing back and standing by is to signal presence. Teachers can signal wait-time by making listening online transparent, while taking care to avoid authoritarian statements that risk bringing discussion to a premature conclusion (Jetton, 2003). Signalling wait-time can occur in several ways, according to suggestions made by teachers and students in this study and supported by the literature on online learning. For example, three ways of signalling wait-time are outlined. First, teachers can signal wait-time firstly by posting responses designed to convey listening, inviting students with contrasting views to contribute in order to enlarge perspectives, or asking a question in connection with what students have contributed (Brookfield \& Preskill, 2005).

Second, wait-time can be conveyed by using minimal encouragers online, in order to signal active listening and proxemics without interrupting the flow of discussion. Drawing on attending or listening skills from counselling, some of these can be applied to online pedagogy (Forbes, 2014; Ivey, Bradford Ivey, \& SimekDowning, 1987). This is known as "positive back-channelling" (Harms, Niederhauser, Davis, Roblyer, \& Gilbert, 2010, p. 77). For example, encouraging, or restating what a person has said involves directly repeating their comments, or making short statements like "tell me more" (Ivey et al., 1987, p. 72).

Third, teachers can make the tacit more explicit "through the use of metacommunication: describing the communication that appears to be taking place" (Jacques \& Salmon, 2007, p. 71). For example, this approach was described by Jacqui (study 1) when commenting on her teacher's tendency to enter discussion to let students know she is there and reading, but is waiting for others to post before she moves the discussion on. In this way, teachers can signal wait-time to students by openly explaining that they are present but standing back, so that wait-time is not mistaken for absence. This strategy differentiates a productive pause in discussion from discussion that has stalled or derailed. This consideration of students' perceptions of absence, juxtaposed with teachers' struggles to balance wait-time and avoid dominance of discussion is an illustration of how insight into the participants' perspectives can inform decision-making about teaching and learning. In theoretical terms, this is also an illustration of how the space of difference between students and teachers can be leveraged as a pedagogical space.

\section{To grade or not to grade?}

Within the literature, one strand of thought assumes that there is little choice but to grade student discussion in a university context (e.g., Arend, 2007; Dennen, 2005; Earl \& Cong, 2011). For the most part, this is because the grading is deemed necessary to motivate students to participate. The assignment of grades to discussion has been questioned by key commentators like Jacques and Salmon (2007), and Brookfield and Preskill (2005), with the former regarding grading as a concern due to the attempt to force participation (Jacques \& Salmon, 2007). While in agreement with these concerns about debasing the quality of 
contributions and promoting individual credit over the development of shared understandings, Brookfield and Preskill have acknowledged the tension between grading discussion and shifting rewards away from discussion altogether. It is unrealistic and arguably unfair to expect participants to devote time and energy to discussion if they are instead, rewarded for work undertaken elsewhere while discussion is marginalised (Garrison \& Anderson, 2003; LaPointe, 2007).

A dilemma here concerns how to encourage time-poor students (and teachers) to accord sufficient priority to learning through online discussion, while promoting higher order thinking, deep learning, and community, and discouraging a purely instrumental approach to summative assessment. This calls for a strategic approach. Philosophically, extrinsic motivation via grading is not the best model to encourage deep learning in higher education (Ebrahimi et al., 2016). Although extrinsic motivation may be effective in terms of getting students to post, it is not going to help them to engage in anything beyond surface learning, and it will not promote commitment to their professional and learning communities. Recent studies of assessment for learning in online contexts have prioritised student reflexivity, agency, and identity (Charteris, Quinn, Parkes, Fletcher, \& Reyes, 2016). Strategically, discussion needs to be:

- $\quad$ an expectation, in keeping with the students' obligation to the learning community;

- $\quad$ subject to student reflection and self-assessment, to promote meta-cognition and deep approaches to learning; and

- closely linked to other assessed work, complementing the discussion. (The summative assessment tasks should be contingent upon commitment to online discussion.)

With these strategies in place, the discussion itself need not be graded to incentivise or reward participation.

\section{The lingo}

The tension between plain language and jargon can be analysed in terms of power and voice. It is necessary to consider how the styles can be reconciled in a way that respects participants' knowledge while enhancing learning potential. When the emphasis is on formal, academic language, it may be seen as promoting "displays of rhetorical power" (Collison, Elbaum, Haavind, \& Tinker, 2000, p. 25). Teachers who use formal language may reinforce hierarchy, accrual of power, and a shift to centre stage as authoritarian figures (Collison et al., 2000; Fauske \& Wade, 2003; Jetton, 2003). This language can serve to intimidate and discourage students, by associating online discussion with "an exercise in status-building, rather than a free exchange of ideas" (Jetton, 2003, p. 181). The core issues were summed up effectively by Brookfield and Preskill (2005) in terms of "how we privilege certain ways of speaking and conveying knowledge and ideas, who has the power to define appropriate forms and patterns of communication, and whose interests these forms and patterns serve" (p. 146). As mentioned, the students in our study and those in Jetton's (2003) work with pre-service teachers preferred free-flowing, accessible language. A consistent emphasis on student voice values the language that students bring to class. However, in the spirit of higher education, the goal is to enable students to think more deeply, with the language that accompanies greater complexity.

\section{Reading to learn}

It would seem that there is a need for clarification of the purpose of literature in online discussion. When negotiating guidelines for online discussion in higher education, teachers and students need to give consideration to how personal and professional experience and how learning from literature can best be incorporated into the online discussion. The teachers in study 1 expected that discussion would have a strong literature base, so that students engaged in reading in order to prepare for discussion of key professional ideas (Brookfield \& Preskill, 2005). The teachers did expect students to read the literature associated with their field of study, and, in turn, expected discussion to reflect this reading. Taking a closer look at the place and purpose of the text, the teachers explained that they regarded reading as a way of enlarging students' awareness of wider perspectives, since they expected engagement with literature to generate new insights and ways of interpreting the phenomenon of study. Literature provides theoretical grounding and key conceptual understandings, couched in the language and terminology of the profession. For these reasons, the teachers looked to online discussion for evidence that students were reading. In turn, the students in study 1 felt compelled to show they were reading and to reference literature in their discussion posts, but complained that this constrained the discussion and promoted excessive use of verbatim quotations. The students regarded this use of literature as detrimental to discussion. Students 
require clear guidance about how to effectively incorporate literature in discussion in meaningful ways that move beyond strings of quotations.

\section{Conclusion and implications}

A synthesis of our studies has enabled the identification of key misunderstandings between tertiary teachers and students in online classes. These are summarised in Table 1.

Table 1

Key misunderstandings between tertiary teachers and students

\begin{tabular}{llll}
\hline $\begin{array}{l}\text { Area of } \\
\text { misunderstanding }\end{array}$ & Teacher intention & Student perception & Common ground \\
\hline Presence & $\begin{array}{l}\text { Standing back to leave } \\
\text { space }\end{array}$ & Absence & $\begin{array}{l}\text { Standing by } \\
\text { Signal presence }\end{array}$ \\
$\begin{array}{l}\text { Formative/summative } \\
\text { dimensions }\end{array}$ & $\begin{array}{l}\text { Encourage } \\
\text { participation }\end{array}$ & $\begin{array}{l}\text { Compliance; } \\
\text { attendance }\end{array}$ & $\begin{array}{l}\text { Tutorial followed by } \\
\text { secondary artefact }\end{array}$ \\
Language & Induction & Obstruction & Meta-language \\
Literature & $\begin{array}{l}\text { Interpret } \\
\text { Critique }\end{array}$ & $\begin{array}{l}\text { Compliance, } \\
\text { quote }\end{array}$ & Paraphrase, model \\
\hline
\end{tabular}

Lessons to be learned in higher education are that when teachers intend to empower students, by allowing freedom, students can sometimes perceive the lack of overt presence as negligence. While it might be tempting to blame students for adopting a passive approach to their studies, the situation is not helped when teachers take a passive approach by standing back from interaction. Abandoning students does not automatically empower them. Instead, we propose tacit intentions be rendered more explicit through clear articulation of purpose and processes. Teachers who explain and model reciprocal expectations stand a chance of active empowerment of students.

Our data shows that students in our higher education context prefer free-flowing, spontaneous language, and dislike direct quotations from literature. Meanwhile teachers struggle with a tension between standing back to allow space for student voice while ensuring more intensive scaffolding of student learning. The experiences of teachers and students differed in terms of the style of language deemed most productive for learning., that is, the teachers aimed to model specialist terminology, and crafted compositions. Meanwhile, students found discussion most relevant when it was characterised by plain language, practical insight, and free-flowing authenticity. There was, however, commonality in the reported experiences of teachers and students appreciated the value of weaving classroom and professional practice with the personal and the theoretical. Both students and teachers valued the sharing of multiple perspectives. An area of contention for both students and teachers concerned the balance between learning through discussion and the use of discussion as a summative assessment task. Identifying these issues and comparative viewpoints suggests areas for negotiation between students and teachers in higher education, and may highlight questions to raise in other contexts.

The findings suggest there is a need to work with students to establish guidelines for online discussions. Following this, there is a need for ongoing negotiation once the class is underway online, in order to "modify expectations collaboratively with students", as Fauske and Wade (2003, p. 148) have suggested. Teachers need to attend to how students are experiencing teaching and learning throughout their course, and communicate about problems that emerge along the way (Brookfield \& Preskill, 2005).

We are cautious about generalising the findings of our studies as there may be limited transferability between the experiences and expectations of these participants, and those of any other population. Nevertheless, as Wenger (1999) reminded us, "a perspective is not a recipe; it does not tell you what to do. Rather, it acts as a guide about what to pay attention to, what difficulties to expect, and how to approach problems" (p. 9). Thus, while the perspectives themselves may be illustrative, our studies have identified concerns that may be applicable to others and raise questions in other contexts. 
Drawing on the findings of the two studies, and in particular on the common ground derived, a number of guiding principles for online discussion are offered below.

- Work with students to co-construct learning intentions. Avoid assuming what students expect. Instead ask directly and negotiate openly, in order to establish shared understandings and explicit expectations.

This can occur via a rapport-building exercise at the beginning of the semester, inviting participants to share their goals for the course, their previous experiences of online study, and what they expect of peers and teachers in online discussion for learning purposes. Students and teachers can work together to generate shared protocols for online discussion by brainstorming what they have found does/does not work and collating a set of expectations. These initial discussion guidelines can then be revisited at later points in the course for further critique and modification (Forbes, 2015).

- Clarify expectations around language, and in particular, how to integrate academic literature into discussion, by weaving meaning and paraphrasing with appropriate citation, but avoiding overuse of verbatim quotations.

Just as direct instruction can be helpful for students learning to write essays, so too can a direct approach to modelling and skill-based instruction be helpful for novices learning to participate in academic online discussion. This might involve showing students exemplars of online discussion posts that effectively integrate literature alongside attempts that rely heavily on verbatim quotations. Exercises in talking about literature without quoting, summarising key ideas from sections of literature, and transforming quotations into one's own words, are all useful approaches to demonstrating how to weave literature effectively into discussion.

- Ensure that ground rules stipulate netiquette and lay a foundation for respectful and responsive communication. Fundamentals here are likely to involve the obligation to be actively involved in discussion, to strive for co-construction, and to respond respectfully.

Online discussion works best when all participants are actively involved, not just posting to be seen, but actually reading what others have written and conveying interest with direct responses to others by name. Polite engagement that shows classmates their input is valued can be built into protocols.

- Strive to be actively present (at least once in 2 days) and to connect with students by following the same guidelines and generally reciprocate.

Expectations are best shared by both teachers and students alike. Resentment or apathy can result if a teacher does not walk the talk by turning up to class to contribute.

- When monitoring discussion, signal presence through metacommunicative cues.

It is necessary to show that one is standing by, attentively, listening or reading online. Students only know the teacher is there when the teacher posts. At times, it is important to signal listening and convey presence in a way that does not interrupt the flow of the conversation or bring the discussion to an abrupt halt. Metacommunicative cues let participants know their posts are being read. A teacher might post a brief comment explicitly saying "I am here, standing by, reading your discussion, but I want to hear more from others. I look forward to further ideas". This is the text-based online equivalent of a nod, a minimal encourager ("uh huh"), or "tell me more" (Forbes, 2013).

- Emphasise formative interaction, giving feedback and encouraging students to do likewise. Be receptive to and actively elicit student feedback.

Engaging in discussion with students is an opportunity to identify gaps in knowledge and to probe for deeper understanding. When interacting in this way via online discussion, the emphasis is on learning through discussion, by questioning, making suggestions, and issuing challenges to construct new learning. Students and teachers can both take part in this feedback exchange via peer feedback and feedback on 
teachers' thinking. For example, this can include asking students for feedback on guidelines for their own class discussions, and for ideas to take forward to new classes.

- Design summative assessment so that it is contingent upon the discussion, and contains a component that requires students to audit their own discussion, producing a reflection and illustrating it with samples from their own discussion entries.

Students are encouraged/required to use literature from their field, as well as empirical investigation in many tertiary assignments, and can similarly be encouraged to cite recent discussions with peers that have influenced their thinking. Assignments may require students to return to previous online discussions in order to analyse the posts and learning involved. Producing a reflective summary, with quotes to illustrate the student's involvement can be a valid means of assessing student learning through online discussion.

Ultimately, this synthesis reveals a little of the clash in participant experiences and expectations of online learning. Highlighting these misunderstandings enables us to engage with them in order to generate possibilities for negotiation, change, and improvement. In terms of these possibilities, we have suggested pedagogical strategies for teachers to trial and to evaluate with student input. By making the misunderstandings visible, we render them revisable (Halse \& Honey, 2010), in pursuit of common ground.

\section{References}

Akyol, Z., \& Garrison, D. R. (2008). The development of a community of inquiry over time in an online course: Understanding the progression and integration of social, cognitive and teaching presence. Journal of Asynchronous Learning Networks, 12(3/4), 3-22. https://doi.org/10.24059/olj.v12i3.66

Arend, B. D. (2007). Course assessment practices and student learning strategies in online courses. Journal of Asynchronous Learning Networks, 11(4), 3-17.

Bates, A. W. (2005). Technology, e-learning and distance education (2nd ed.). Oxon: Routledge.

Beetham, H. (2007). An approach to learning activity design. In H. Beetham, \& R. Sharpe (Eds.), Rethinking pedagogy for a digital age: Designing and delivering e-learning (pp. 26-40). New York, NY: Routledge.

Bender, T. (2003). Discussion-based online teaching to enhance student learning: Theory, practice and assessment. Sterling, VA: Stylus.

Ben-Peretz, M., \& Kupferberg, I. (2007). Does teachers' negotiation of personal cases in an interactive cyber forum contribute to their professional learning? Teachers and Teaching: Theory and Practice, 13(2), 125-143. https://doi.org/10.1080/13540600601152462

Bischoff, A. (2000). The elements of effective online teaching: Overcoming the barriers to success. In K. W. White, \& B. H. Weight (Eds.), The online teaching guide: A handbook of attitudes, strategies, and techniques for the virtual classroom (pp. 57-72). Boston, MA: Allyn \& Bacon.

Blignaut, A. S., \& Trollip, S. R. (2003). Measuring faculty participation in asynchronous discussion forums. Journal of Education for Business, 78(6), 347-353.

https://doi.org/10.1080/08832320309598625 Brookfield, S., \& Preskill, S. (2005). Discussions as a way of teaching: Tools and techniques for democratic classrooms (2nd ed.). San Francisco, CA: Jossey-Bass.

Charteris, J., Quinn, F., Parkes, M., Fletcher, P., \& Reyes, V. (2016). e-Assessment for learning and performativity in higher education: A case for existential learning. Australasian Journal of Educational Technology, 32(3), 112-122. https://doi.org/10.14742/ajet.2595

Collison, G., Elbaum, B., Haavind, S., \& Tinker, R. (2000). Facilitating online learning: Effective strategies for moderators. Madison, WI: Atwood.

Dennen, V. P. (2005). From message posting to learning dialogues: Factors affecting learner participation in asynchronous discussion. Distance Education, 26(1), 127-148. https://doi.org/10.1080/01587910500081376

Durrington, V. A., \& Chien, Y. (2004). It's the same only different. Quarterly Review of Distance Education, 5(2), 89-100.

Earl, K., \& Cong, Y. (2011). Chinese international students' experience of studying online in New Zealand. Waikato Journal of Education, 16(1), 93-105. https://doi.org/10.15663/wje.v16i1.73

Ebrahimi, A., Faghih, E., \& Marandi, S. S. (2016). Factors affecting pre-service teachers' participation in asynchronous discussion: The case of Iran. Australasian Journal of Educational Technology, 32(2), 115-129. https://doi.org/10.14742/ajet.2712 
Ellsworth, E. (1997). Teaching positions: Difference, pedagogy and the power of address. New York, NY: Teachers College Press.

Engeström, Y. (1987). Learning by expanding: An activity-theoretical approach to developmental research. Helsinki: Orienta-Konsultit.

Fauske, J., \& Wade, S. E. (2003). Research to practice online: Conditions that foster democracy, community, and critical thinking in computer-mediated discussions. Journal of Research on Technology in Education, 36(2), 137-153. https://doi.org/10.1080/15391523.2003.10782409

Ferdig, R. E., \& Roehler, L. R. (2003). Student uptake in electronic discussions: Examining online discourse in literacy preservice classrooms. Journal of Research on Technology in Education, 26(2), 119-136. https://doi.org/10.1080/15391523.2003.10782408

Forbes, D. L. (2013). Footprints: Participant perspectives informing pedagogy for asynchronous online discussion in initial teacher education (Doctoral dissertation). University of Waikato, Hamilton, New Zealand. Retrieved from https://hdl.handle.net/10289/7108

Forbes, D. L. (2014). Listening and learning through ICT with digital kids: Dynamics of interaction, power and mutual learning between student teachers and children in online discussion. In K. P. H. Sullivan, P. E. Czigler, \& J. M. S. Hellgren (Eds.), Cases on professional distance education degree programs and practices: Successes, challenges, and issues (pp. 148-175). Hershey, PA: Infomation Science Reference.

Forbes, D. L. (2015). Legacies of learning: Negotiating guidelines for online discussion. In N. Wright, \& D. Forbes (Eds.), Digital smarts: Enhancing learning \& teaching (pp. 82-103). Hamilton: Wilf Malcolm Institute of Educational Research.

Garrison, D. R. (2011). E-learning in the 21st century: A framework for research and practice (2nd ed.). London: Routledge.

Garrison, D. R., \& Anderson, T. (2003). E-learning in the 21st century. London: Routledge Falmer.

Garrison, D. R, Anderson, T., \& Archer, W. (2001). Critical thinking, cognitive presence, and computer conferencing in distance education. American Journal of Distance Education, 15(1), 7-23. https://doi.org/10.1080/08923640109527071

Gedera, D. S. P. (2014). Mediational engagement in E-learning: An Activity Theory analysis (Thesis, Doctor of Philosophy (PhD)). University of Waikato, Hamilton, New Zealand. Retrieved from https://hdl.handle.net/10289/8847

Gedera, D. S. P., Williams, J., \& Wright, N. (2015). Identifying factors influencing students' motivation and engagement in online courses. In C. Koh (Ed.), Motivation, leadership and durriculum design. Engaging the net generation and 21st century learners (pp. 13-23). Singapore: Springer. https://doi.org/10.1007/978-981-287-230-2

Goodyear, P. (2002). Psychological foundations for networked learning. In C. Steeples, \& C. Jones (Eds.), Networked learning: Perspectives and issues (pp. 49-75). London: Springer.

Halse, C., \& Honey, A. (2010). Unraveling ethics: Illuminating the moral dilemmas of research ethics. In W. Luttrell (Ed.), Qualitative educational research: Readings in reflexive methodology and transformative practice (pp. 123-138). New Jersey, NJ: Routledge.

Harms, C., Niederhauser, D. S. N., Davis, N. E., Roblyer, M. D., \& Gilbert, S. B. (2010). Educating educators for virtual schooling: Communicating roles and responsibilities. In C. M. Stewart, C. C. Schifter, \& M. E. Markaridian (Eds.), Teaching and learning with technology: Beyond constructivism (pp. 70-86). New York, NY: Routledge.

Hew, K. F., Cheung, W. S., \& Ng, C. S. L. (2010). Student contribution in asynchronous online discussion: A review of the research and empirical exploration. Instructional Science, 38(6), 571-606. https://doi.org/10.1007/s11251-008-9087-0

Ivey, A. E., Bradford Ivey, M., \& Simek-Downing, L. (1987). Counseling and psychotherapy (2nd ed.). Boston, MA: Allyn and Bacon.

Jacques, D., \& Salmon, G. (2007). Learning in groups: A handbook for face-to-face and online environments (4th ed). London: Routledge.

Jetton, T. L. (2003). Using computer-mediated discussion to facilitate preservice teachers' understanding of literacy assessment and instruction. Journal of Research on Technology in Education, 36(2), 171191. https://doi.org/10.1080/15391523.2003.10782411

Kehrwald, B. A. (2008). Understanding social presence in text-based online learning environments. Distance Education, 29(1), 89-106. https://doi.org/10.1080/01587910802004860

Ko, S., \& Rossen, S. (2004). Teaching online: A practical guide. Boston, MA: Houghton Mifflin.

LaPointe, D. K. (2007). Pursuing interaction. In J. M. Spector (Ed.), Finding your voice online: Stories told by experienced online educators (pp. 83-103). London: Lawrence Erlbaum. 
Laurillard, D. (2002). Rethinking university teaching: A conversational framework for the effective use of learning technologies (2nd ed.). London: Routledge Falmer.

Loughran, J. (1999). Researching teaching: Methodologies and practices for understanding pedagogy. London: Falmer Press.

Loughran, J. (2006). Developing a pedagogy of teacher education: Understanding teaching and learning about teaching. London: Routledge.

Lynch, M. M. (2004). Learning online: A guide to success in the virtual classroom. London: Routledge Falmer.

Marton, F., \& Booth, S. (1997). Learning and awareness. New Jersey, NJ: Lawrence Erlbaum.

Mortera-Gutiérrez, F. (2006). Faculty best practices using blended learning in e-learning and face-to-face instruction. International Journal on E-learning, 5(3), 313-337.

Palloff, R., \& Pratt, K. (2005). Collaborating online: Learning together in community. San Francisco, CA: Jossey-Bass.

Rowe, M. (1986). Wait time: Slowing down may be a way of speeding up! Journal of Teacher Education, 37, 43-50. https://doi.org/10.1177/002248718603700110

Salmon, G. (2011). E-moderating: The key to teaching and learning online (3rd ed.). New York, NY: Routledge.

Sharpe, R., Beetham, H., \& de Freitas, S. (2010). Rethinking learning for a digital age: How learners are shaping their own experiences. New York, NY: Routledge.

Sims, R. C., \& Bovard, B. (2007). Using elaborations of online presence to foster critical thinking and reflection. In J. M. Spector (Ed.), Finding your voice online: Stories told by experienced online educators (pp. 163-182). London: Lawrence Erlbaum.

Tallent-Runnels, M. K., Thomas, J. A., Lan, W. Y., Cooper, S., Ahern, T. C., Shaw, S. M., \& Liu, X. (2006). Teaching courses online: A review of the research. Review of Educational Research, 76(1), 93-135. https://doi.org/10.3102\%2F00346543076001093

Visser, L. (2007). Online teaching experiences in higher education: Obstacles and opportunities. In J. M. Spector (Ed.), Finding your voice online: Stories told by experienced online educators (pp. 105-121). London: Lawrence Erlbaum.

Vygotsky, L. S. (1978). Mind and society: The development of higher psychological processes. Cambridge, MA: Harvard University Press.

Weimer, M. (2002). Learner-centered teaching: Five key changes to practice. San-Francisco, CA: Jossey-Bass.

Wenger, E. (1999). Communities of practice: Learning, meaning, and identity. Cambridge: Cambridge University Press.

Zhang, D., \& Nunamaker, J. F. (2003). Powering e-learning in the new millennium: An overview of elearning enabling technology. Information Systems Frontiers, 5(2), 207-216. https://doi.org/10.1023/A:1022609809036

Corresponding author: Dianne Forbes, dianne.forbes@waikato.ac.nz

Australasian Journal of Educational Technology (C) 2019.

Please cite as: Forbes, D. L., \& Gedera, D. S. P. (2019). From confounded to common ground: Misunderstandings between tertiary teachers and students in online discussions. Australasian Journal of Educational Technology, 35(4), 1-13. https://doi.org/10.14742/ajet.3595 